\title{
The Role of Ownership's Concentration Moderating Dividend Policy Effects on Firm Value
}

Submitted 14/12/19, $1^{\text {st }}$ revision 09/02/20, $2^{\text {nd }}$ revision $15 / 03 / 20$, accepted $02 / 04 / 20$

\author{
Rudi Zulfikar ${ }^{1}$, Nana Nofianti ${ }^{2}$, Kurniasih Dwi Astuti ${ }^{3}$, \\ Meutia Meutia $^{4}$, Aldi Ramadan ${ }^{5}$
}

\begin{abstract}
:
Purpose: The main aim of this research is to examine the role of ownership's concentration moderating of dividend policy effects on firm value.

Design/methodology/approach: For the empirical part we have used a sample of 23 companies with five years of observation a total of 115 data observations. The retrieval of data observations in the sample was based on certain criteria in the period of 2014-2018.

Findings: The result supported the hypothesis that dividend policy had a positive effect on firm value. Besides, the concentration of ownership weakened the relationship between the dividend policy and the firm value. Results proved that companies in Indonesia whose ownership had been owned by families would affect management policies, such as dividend policy.

Practical Implications: Therefore, the concerns of business ethics in Indonesia had been weak. It was supporting the allegation that law enforcement in Indonesia was weak.

Originality/value: The Novelty of testing the concentration of ownership as a moderating variable.
\end{abstract}

Keywords: Firm value, dividends policy, ownership concentration.

JEL Codes: H2, H21, J54, Q13.

Paper Type: Research article.

\footnotetext{
${ }^{1}$ University of Sultan Ageng Tirtayasa Serang Banten, Indonesia, rz-zulfikar72@untirta.ac.id

${ }^{2}$ University of Sultan Ageng Tirtayasa Serang Banten, Indonesia, nnofianti@untirta.ac.id

${ }^{3}$ University of Sultan Ageng Tirtayasa Serang Banten, Indonesia, nien_rz@hotmail.com

${ }^{4}$ University of Sultan Ageng Tirtayasa Serang Banten, Indonesia, tia_almer@yahoo.co.id

${ }^{5}$ University of Sultan Ageng Tirtayasa Serang Banten, Indonesia,

aldiramadan104@gmail.com
} 


\section{Introduction}

Firm value is an investor's assessment of a company that was associated with the company's share price (Brigham and Houston, 2001). Through the high share price the firm value will be high, so it will increase the market reliance on the prospects of the company in the future (Cremers et al., 2017) The firm value of industrial manufacturing in Indonesia was measured by using the Price to Book Value (PBV) as indicated in Figure 1.

Figure 1. Listing of Firm Value in the Indonesia Stock Exchange 2014-2018

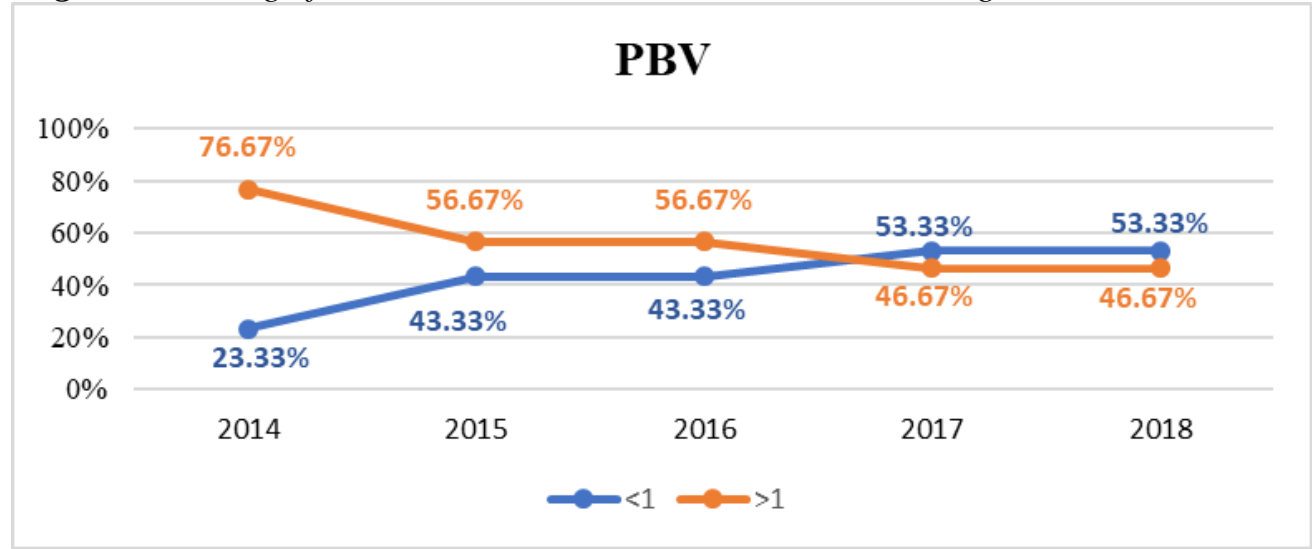

Source: Indonesia Stock Exchange.

Based on this Figure there was a decline in the industrial manufacturing firm value in the period 2014-2018. In 2014, listed industrial manufacturing firms having PBV below one was $23,33 \%$ of the total while in 2018 had increased to 53,33\%. The firm value, which is less than 1, illustrated that the company was in undervalued condition (Kuzey and Uyar, 2017) meaning that the company's shares are rated lower than its book value (Damodaran, 2016). Meanwhile, the total number of companies with PBV more than 1 had decreased from 76,67\% in 2014 to $46,67 \%$ in 2018. PBV greater than 1 is the case of an overvalued case. For companies that had PBV higher than 1 is a favourable condition as it is pointed out by Willim (2015). Thus, there was a decrease in PBV for the industrial manufacturing companies during the period 2013-2017.

One of the suspected factors that could affect the firm's value is the dividend policy. According to Nippel (2008), the firm value decreased while there were reducing dividend payments. This is because the dividends have a signalling effect as pointed by Okoro, Ezeabasili and Alajekwu, (2018). The increase in dividend payments was being regarded as a positive signal in conveying information about the company's future income prospects, so it increased the firm value (Ismail et al., 2019a; 2019b). Conversely, a reduction in the dividend payments was being regarded as a negative signal about future income prospects to lower the firm value (Budagaga, 2017). According to Brigham and Houston (2001) the dividend policy was a decision on 
how large profits that will be paid out as dividends or retained to be invested back into the company. Furthermore, Chen and Dhiensiri (2009) argued that the dividend policy was essential for investors because it was able to provide certainty about the health of financial companies and attract the investors' interests who seek for fixed income. The dividend payments, which were done consistently and stably, could affect the shares' price, and the growth period ahead (Shams Koloukhi, Taghavi Moghaddam and Parsian, 2016; Kambey et al., 2018; Kurniawti et al., 2019).

Anton's research (2016) in Romania and Subramaniam's (2018) in Malaysia concluded that management could increase the firm value. Research conducted by Senata (2016) in Indonesia proved that the increase of the distributed dividends became a signal to investors about the prospects for company's growth in the future. Meanwhile, Marangu and Jagongo (2015) in Kenya proved that the dividend policy got negative impacts on the firm value. Furthermore, Gharaibeh and Qader (2017) in Saudi Arabia concluded that the dividend policy was not the main factor that affected the firm's value.

Managers to consider policies that allegedly have opted for more profit-making have been taken to carry out the expansion and do not distribute dividends to shareholders. This was because the manager had an interest in pursuing prosperity by accepting the premiums / incentives in a performance that was achieved and managed in a program called a bonus program (Watts and Zimmerman, 2001).

Some studies have previously had inconsistent results. It was suspected that other variables could affect the concentration of ownership. In Asian countries, including Indonesia, most ownership shares were concentrated with overall main ownership shares (Zhuang, Edwards and Capulong, 2001). The structure of centralized ownership has shown the potential of shareholders responsible for managing the company (Prencipe, Bar-Yosef and Dekker, 2014). It would lead to a difference in interests between the majority shareholders and minority shareholders, so the majority owner had an opportunity to suppress the rights of the minority owner (Mitton, 2002). The majority owner tends to make a policy more favourable to his interests, such as the negative minority owners of those interests (Claessens et al., 2000; Sakir et al., 2019; Setyawan et al., 2014). In Indonesia, the structure of companies' governance was managed by majority families (Lukviarman, 2004; Bernadus et al., 2018). This opinion was supported by an Indonesian business survey conducted by Price Waterhouse and Copper in 2014 proved that more than $95 \%$ of businesses in Indonesia were owned by families' companies.

Crisostomo and Brandao (2016) in Brazil proved that the concentration of ownership had adverse effects on the distributed dividends. Furthermore, the research of Boubraki et al. (2011) and Reyna (2015) in Canada proved that the concentration of ownership had adverse effects on the firm value. Thus, the concentration of ownership had predicted to weaken the dividends policy influences on the firm value. 


\section{Theoretical Framework}

This study used the agency theory to explain the occurred problems in dividend policy. Interest conflicts are the essence of agency problems that have been arisen from the delegation of management functions from principals to agents (Jensen and Meckling, 1976). Based on the assumption that both sides, managers and investors, are utility maximisers (maximizing their profits) in determining the dividend policy allegedly chose to withhold incomes for their interests and did not pay attention to the welfare of the shareholders. Thus, the occurred agency problem could decrease the distributed dividends and reduce the firm value.

The ownership concentration was expected to reduce agency problems that occurred between principals and agents. It has happened because the majority of shareholders could use the owned controls to put, pick, and oversee the management following its interests. The existence of management who worked with promoting the interests of majority shareholders would bring the agency conflict, such as conflict of agency among the shareholders in majority and minority stakes (Brian and Martani, 2014). Thus, the authors concluded that the existence of ownership concentration did not resolve agency conflict entirely. However, it caused other agency conflicts among majority shareholders and minority shareholders.

The firm value was an investor's assessment of a company associated with the company's share value (Brigham and Houston, 2001). The firm value was reflected by its share price, if the share price were higher, so the firm value will be higher. The higher share price could increase public trust in the company's prospects (Hermuningsih, 2013). Therefore, the company tried to increase the firm value by maximizing its share price (Pangulu and Maski, 2014). The firm value in this study was measured by using the Price to Book Value, the comparison between the market value of the share and the book value of the share as a ratio.

Meanwhile, according to Brigham and Houston (2001), the dividend policy was the decision of how much profit now will be paid out as dividends or detained to be invested back into the company. By dividend policy, the financial health of the company could be known (Crisostomo and Brandao, 2016). Besides, it was able to improve the shareholders' trust of the company through the dividend policy (González, Guzmán, Pombo and Trujillo, 2014). The dividend policy in this study was proxied by the Dividend Payout Ratio (DPR). The reason for choosing the Dividend Payout Ratio (DPR) was a measure which used by investors to see how a large amount of the dividend payments were carried out by the company (Akani and Sweneme, 2016). Weston and Brigham (2005) concluded that the optimal dividend policy was able to create a balance between dividends now and the growth in the future to maximize the reflected firm value through the share price.

The structure of shares ownership in a country was determined by the strength or the weakness protection of the state towards the shareholders (La porta et al., 1996). The 
concentration of ownership could encourage majority shareholders tended to create a policy that has greater priority to their interests and detrimental to the minority shareholders (Claessens et al., 2000). Furthermore, Claessens et al. (2000) proved that the concentration of ownership in Asia could be measured by using a rate of 10 percent and 20 percent. Furthermore, the research by Lukviarman (2004) concluded that the share ownership of more than 50 percent was the concentrated ownership.

Thus, this research referred to measure the concentration of ownership as in the research by Lukviarman (2004) by using the percentage of share ownership by individuals or companies. Crisóstomo and Brandão (2016) proved that the takeover by the majority shareholders resulted in restricted dividends. Furthermore, the research of Boubraki et al. (2011) and Tachmatzidi (2018; 2019) concluded that the lack of law protection towards the minority shareholders resulted in the agency problem among the majority shareholders and minority shareholders. Thus, the concentration of ownership was predicted to weaken the influence of dividend policy on the firm value.

\section{Research Methodology}

Secondary data form the annual reports of 23 companies selected based on certain criteria, as it is pointed out above in the period of 2014-2018 were used in this study. The sampling was done by using the purposive sampling method, which aimed to obtain a representative sample following the specified criteria.

As a measurement of firm value, we used the Price to Book Value (PBV) that is a ratio between the share price and the book value of the company's share (Brigham and Houston, 2001). The dividend policy that was proxied by the Dividend Payout Ratio (DPR) was used as an independent variable in this study. The DPR was the ratio of dividends per share with earnings per share (Brigham and Houston, 2001). The concentration of ownership was used as a variable moderating in this study. According to Lukviarman (2004), the concentration of ownership could be measured by the proportion of majority share ownership. Meanwhile, the company and leverage measurement were employed as a variable control. Regression model with Moderate Regresion Analysis (MRA) was developed to test the formulated hypotheses (Ghozali, 2016) as follows:

PBVit $=\beta 0+\beta 1$ DPRit $+\beta 2$ KKit $+\beta 3$ DPRit $*$ KKit $+\beta 4$ LEVit $+\beta 5$ SIZEit $+\mathrm{e}$

Where:

PBVit : Firm Value

DPRit : Dividend policy

KKit : Ownership Concentration

SIZEit : Company Measurement

LEVit : Leverage

eit : Error term 


\section{Results and Discussion}

A sample of 23 companies with five years of observation was employed in this study, a total of 115 data observations. Based on Table 1, the firm value (PBV) showed that the mean was 6,47. Furthermore, the dividend policy value (DPR) has a mean value of 0,51 or $51 \%$. It indicated that the dividends distributed by a manufacturing company to the shareholders were still relatively low and has not been optimal. While the concentration of ownership (KK) showed a mean value of 70,14 or $70.14 \%$. It was indicated that there was a concentration of ownership by the very high percentage.

Table 1. Descriptive Statistics

\begin{tabular}{|c|c|c|c|c|c|c|}
\hline & & $\mathbf{N}$ & Min & $\operatorname{Max}$ & Mean & Std. Deviation \\
\hline$\overline{\mathrm{PBV}}$ & & 115 & 0,01 & 3,45 & 6,47 & 0,59 \\
\hline DPR & & 115 & 0,00 & 0,18 & 0,51 & 0,04 \\
\hline LEV & & 115 & 0,01 & 0,06 & 0,37 & 0,01 \\
\hline SIZE & & 115 & 1,11 & 1,36 & 29,01 & 0,09 \\
\hline KK & & 115 & 2,13 & 4,1 & 70,14 & 0,63 \\
\hline $\begin{array}{l}\text { Valid } \\
\text { (listwise) }\end{array}$ & $\mathrm{N}$ & 115 & & & & \\
\hline
\end{tabular}

The control variable consisted of leverage (LEV) revealed that the mean was 0,37 or $37 \%$. It was indicated the needs of companies' funds were financed by debt that is relatively low. Furthermore, the company measurement generated the mean at 29,01. It showed that companies in Indonesia had large companies' measurements (Table 2).

Table 2. Regression Analysis

\begin{tabular}{llll}
\hline Variable & $\begin{array}{l}\text { Regression } \\
\text { Coefficient }\end{array}$ & t count & Sig \\
\hline (Constant) & $-11,99$ & $-1,32$ & 0,193 \\
DPR & 3,19 & 2,25 & 0,003 \\
LEV & 0,479 & 2,91 & 0,083 \\
SIZE & 2,80 & 1,14 & 0,29 \\
KK & 0,68 & 1,16 & 0,00 \\
MODERATION & $-0,70$ & $-2,16$ & 0,006 \\
\hline R Square & 0,55 & & \\
Adjusted R Square & 0,578 & & \\
F & 5,93 & & \\
Sig & 0,00 & & \\
\hline
\end{tabular}

Based on Table 2, the value of the determination coefficient (adjusted R -square) in this research model is 0,578 or $57,8 \%$. It means that the independent variables in 
this study were able to explain the influences on the dependent variable by $37,8 \%$, and the rest was influenced by other variables not included in this research model. Thus, it can be concluded that the model used in this study is accepted and cab be used. Four out of five independent variables are statistically significant. Based on the regression results presented in Table 1 the DPR variable influenced positively the dependent variable with a coefficient 3,19 , the LEV variable with a coefficient 0,479 and the SIZE variable with a coefficient 2,80. The significance level in all cases less than $0.05 \%$.

It can be concluded that the research model has proved that the dividend policy has a positive effect on firm value. Therefore, the first hypothesis of this study is accepted. The testing result showed the compatibility with the results of Anton's research (2016) in Romania concluded that management could increase the firm value by improving the dividend policy in an optimal way. Other research by Senata (2016), contacted in Indonesia, concluded that by increasing the distributed dividends it will work as a signal for investors about the prospects of companies' growth in the future. Furthermore, the research by Nwamaka and Ezeabasili (2017) proved that the dividend policy had a positive effect on firm value. It was caused due to the dividend distribution competently prevented the use of flows of cash surplus in unprofitable investments.

Other results in Table 2 proved that the moderating variable has influenced the firm value with coefficient $-0,70$. It can be concluded that the second hypothesis which suspected that the concentration of ownership weakened the influence of dividend policy on the accepted firm value is approved. The results are in line with the research contacted by Crisostomo and Brandao (2016) in Brazil, stating that the takeover by the majority shareholders caused the limited dividend distribution. The decline of distributed dividends might be affected by the decline of the firm value. Other studies, Boubraki et al. (2011), proved that the concentration of ownership has affected negatively the firm value. Thus, it can be concluded that the concentration of ownership weakened the influences of dividends policy on the firm value (Taqi $e t$ al., 2020). Moreover, the research by Saona and Martin (2016) concluded that if the concentration of ownership increased, it might decrease the firm value. This is because of the takeover by the majority shareholders on the minority shareholders.

The regression coefficient for LEV (leverage) is 0,479 and statistically significant. The magnitude is low concluding that the leverage is ineffective on the firm value. The regression coefficient for SIZE is not statistically significant (significance level $0,29>0,05)$ with $t$ value 1,14 .

\section{Conclusion}

It has been proven that the dividend policy has a positive and statistically significant effect on the firm value of the industrial manufacturing companies listed in Indonesia Stock Exchange in the period under study. It was demonstrated that the 
dividend policy is one of the factors that affects the firm's value. The increase in distributed dividends could increase the firm's value. The concentration of ownership has shown that it may weaken the relationship between the dividend policy and the firm value. It was showed that the concentration of ownership is one of the deciding factors on the firm value. The results are in line with previous studies on the same subject.

\section{References:}

Akani, H.W., Sweneme, Y. 2016. Dividend policy and the profitability of selected quoted manufacturing firms in Nigeria: An empirical analysis. Journal of Finance and Accounting, 4(4), 212-224.

Anton, S.G. 2016. The impact of dividend policy on firm value. A panel data analysis of Romanian listed firms. Journal of Public Administration, Finance and Law, 10, 107112. https://doi.org/10.18551/rjoas.2018-07.06.

Bernadus, D., Utami, C.W., Liliana, L. 2018. Factor analysis of ownership behavior at family business: The case of Indonesia. International Journal of Economics and Business Administration, 6(2), 27-38.

Brigham, E.F., Ehrhardt, M.C. 2011. Financial Management Theory and Practice. South Western Cengage Learning Graphic World Inc., London.

Boubraki, N., Bozec, Y., Laurin, C., Rousseau, S. 2011. Incorporation law, ownership structure, and firm value: evidence from Canada. Journal of Empirical Legal Studies, 8(2), 358-383. https://doi.org/10.1111/j.1740-1461.2011.01212.x.

Budagaga, A. 2017. Dividend payment and its impact on the value of firms listed on Istanbul stock exchange: A residual income approach. International Journal of Economics and Financial Issues, 7(2), 370-376.

Brian, I., Martani, D. 2014. Analysis of the effect of tax avoidance and family ownership on the time of announcement of the company's annual financial statements. Finance and Banking Journal. Vol, 16(2).

Brigham, E.F., Joel, F., Houston, H. 2001. Fundamentals of Financial Management. MacMillan, NY.

Cremers, M., Pareek, A., Sautner, Z. 2017. Short-term investors, long-term investments, and firm value. Recuperado el, 15.

Chen, J., Dhiensiri, N. 2009. Determinants of dividend policy: The evidence from New Zealand. International Research Journal of Finance and Economics, 34(34), 18-28.

Claessens, S., Djankov, S., Lang, L.H. 2000. The separation of ownership and control in East Asian corporations. Journal of Financial Economics, 58(1-2), 81-112. https://doi.org/10.1016/s0304-405x(00)00067-2.

Crisóstomo, V.L., Brandão, J.W. 2016. Ownership Concentration Affects Dividend Policy of the Brazilian Firm. Revista de Finanças Aplicadas, 7(3).

Damodaran, A. 2016. Damodaran on valuation. Security analysis for investment and corporate finance, Vol. 324. John Wiley \& Sons.

Gharaibeh, A.M.O., Qader, A.A. 2017. Factors Influencing Firm Value as Measured by Tobin's Q: Empirical Evidence from the Saudi Stock Exchange. TADAWUL.

González, M., Guzmán, A., Pombo, C., Trujillo, M.A. 2014. Family involvement and dividend policy in closely held firms. Family Business Review, 27(4), 365-385.

Ghozali, I. 2016. Multivariate Analysis Application with IBM SPSS 23 Program, Eighth Edition. Diponegoro University Publisher, Semarang. 
Hermuningsih, S. 2013. The Effect of Profitability, Growth Opportunity, Capital Structure upon the Company Value at the Public Companies in Indonesia. Bulletin Monetary Economics and Banking, 127-148.

Ismail, T., Meutia, M., Ummi, N. 2019a. Enabling management control in improving the performance of SMEs. Management Science Letter, 9(10), 1823-1832.

Ismail, Y.V., Thauid, A., Hadiwidjojo, D., Indrawati, K.N. 2019b. Personality Factors and Servant Leadership on Islamic Microfinance Institution. In: Developments and Prospects of Business Economics and Finance in Muslim Countries, Edited by Thalassinos, I.E., 1-31, NOVA Science Publishers, Inc., ISBN: 978-1-53615-015-5. https://novapublishers.com/shop/developments-and-prospects-of-businesseconomics-and-finance-in-muslim-countries/.

Jensen, M.C., Meckling, W.H. 1976. Agency Costs and the Theory of the Firm. Journal of financial economics, 3(4), 305-360.

Kambey, J.P., Wuryaningrat, N.F., Kumajas, L.I. 2018. Examining leadership and knowledge sharing role on small and medium enterprises innovation capabilities. International Journal of Economics and Business Administration, 6(1), 24-38.

Kurniawti, T.D., Thayib, A., Irawanto, W.D., Rofiq, A. 2019. Influence of Organizational Culture, Servant Leadership, and Trust on the Tacit Knowledge Sharing. In: Developments and Prospects of Business Economics and Finance in Muslim Countries, Edited by Thalassinos, I.E., 151-170, NOVA Science Publishers, Inc., ISBN: 978-1-53615-015-5. https://novapublishers.com/shop/developments-andprospects-of-business-economics-and-finance-in-muslim-countries/.

Kuzey, C., Uyar, A. 2017. Determinants of sustainability reporting and its impact on firm value: Evidence from the emerging market of Turkey. Journal of cleaner production, 143, 27-39.

La Porta, R., Lopez-de-Silanes, F., Shleifer, A., Vishny, R.W. 2000. Agency problems and dividend policies around the world. The journal of finance, 55(1), 1-33. https://doi.org/10.1111/0022-1082.00199.

Lukviarman, N. 2004. Ownership structure and firm performance: the case of Indonesia. Doctoral dissertation, Curtin University.

Mitton, T. 2002. A cross-firm analysis of the impact of corporate governance on the East Asian financial crisis. Journal of financial economics, 64(2), 215-241.

Meutia, M., Ismail, T. 2017. Strategy formation process and management control. International Journal of Economic Perspectives, 11(3), 384-391.

Marangu, K., Jagongo, A. 2015. Price to Book Value Ratio and Financial Statement Variables: A Study of Companies Quoted at Nairobi Securities Exchange, Kenya. International Journal of Finance \& Policy Analysis, 7.

Nwamaka, O.C., Ezeabasili, V. 2017. Effect of Dividend Policies on Firm Value: Evidence from quoted firms in Nigeria. International Journal of Management Excellence, 8(2), 956-967. https://doi.org/10.17722/ijme.v8i2.290.

Nippel, P. 2008. The Impact of a Firm's Payout Policy on Stock Prices and Shareholders' Wealth in an Inefficient Market. In 21st Australasian Finance and Banking Conference.

Okoro, C.O., Ezeabasili, V., Alajekwu, U.B. 2018. Analysis of the determinants of dividend payout of consumer goods companies in Nigeria. Annals of Spiru Haret University, Economic Series, 9(1), 141-165.

Prencipe, A., Bar-Yosef, S., Dekker, H.C. 2014. Accounting research in family firms: Theoretical and empirical challenges. European Accounting Review, 23(3), 361385 . 
Pangulu, A.L., Maski, G. 2014. The Effect of Profitability, Growth Opportunity, and Capital Structure on Company Value. Study of Banking Companies Listed on the Indonesia Stock Exchange Period 2011-2013. FEB Student Scientific Journal, 3(1).

Reyna, J.M.S.M. 2015. Ownership structure and its effect on dividend policy in the Mexican context. Contaduría y Administración, 62(4), 1199-1213. https://doi.org/10.1016/j.cya.2015.12.006.

Sakir, A., Salim, U., Djumahir, D., Drazuli, A. 2019. The influence of Informational Advantage and Investors' Behaviour Toward the Stock Trading Performance. In: Developments and Prospects of Business Economics and Finance in Muslim Countries, Edited by Thalassinos, I.E., 170-199, NOVA Science Publishers, Inc., ISBN: 978-1-53615-015-5. https://novapublishers.com/shop/developments-andprospects-of-business-economics-and-finance-in-muslim-countries/.

Setyawan, A.A., Dharmmesta, S.B., Purwanto, M.B., Nugroho, S.S. 2014. Model of Relationship Marketing and Power Asymmetry in Indonesia Retail Industry. International Journal of Economics and Business Administration, 2(4), 108-127.

Shams Koloukhi, A., Taghavi Moghaddam, A., Parsian, D. 2016. The Effect of Working Capital Management on the Decisions of Financial Provision and Profitability. In Iranian 14th National Conference on Accounting, Urmia University.

Senata, M. 2016. The Effect of Dividend Policy on Company Value Listed on the Lq-45 Index of the Indonesia Stock Exchange. Journal of Microeconomic Entrepreneurs: JWEM, 6(1), 73-84.

Saona, P., San Martín, P. 2016. Country-level governance variables and ownership concentration as determinants of firm value in Latin America. International Review of Law and Economics, 47, 84-95. https://doi.org/10.1016/j.irle.2016.06.004.

Subramaniam, V. 2018. Family Ownership and Dividend Policy: Empirical Evidence from Malaysia. International Journal of Business and Management, 13(5). https://doi.org/10.5539/ijbm.v13n5p112

Tachmatzidi, I. 2018. Takeover Defenses in the United Kingdom. International Journal of Economics and Business Administration, 6(4), 105-118.

Tachmatzidi, I. 2019. Comparative Analysis of Takeover Defenses in Strong and Weak Economies: The Paradigm of the UK and Greece. European Research Studies Journal, 22(2), 254-264.

Taqi, M., Sabaruddinsah, S., Ismail, T., Meutia, M. 2020. Antecedent Variables and Consequences of Religiosity on Fraud. International Journal of Financial Research, 11(1), 43-48.

Weston, J.F., Brigham, E.F. 2005. Intermediate Financial Management. MacMillan, NY.

Willim, A.P. 2015. Price book value \& Tobin's Q: Which one is better for measure corporate governance. European Journal of Business and Management, 7(27), 74-79.

Watts, R.L., Zimmerman, J.L. 2001. Towards a Positive Theory of the Determination of Accounting. The Accounting Review, 200(1).

Zhuang, J., Edwards, D., Capulong, M.V.A. 2001. Corporate Governance and Finance in East Asia: A Study of Indonesia, Republic of Korea, Malaysia, Philippines and Thailand. Asian Development Bank. 